\title{
Analysis of Information Quality, Trust and Satisfaction on Customer Participation (Case Study on Customer Online Shop Shopee in Rantauprapat)
}

\author{
Auliya Fadhillah', Yuniman Zebua ${ }^{2}$, Yudi Prayoga ${ }^{3}$ \\ ${ }^{1,2,3}$ Faculty of Economics and Business, Universitas Labuhanbatu, Indonesia \\ aulia17ip@gmail.com,oinitehezeb@gmail.com,prayogayudi03@gmail.com
}

\begin{abstract}
Online shopping can be accessed through digital applications known as e-commerce applications. One of e-commerce the wellknown in Indonesia is shopee. The main purpose of this research is to determine the factors that influence the variables of Information Quality, Trust, Satisfaction with Customer Participation in Shopee Online Shop Customers in Rantauprapat. This study uses nonprobability sampling method with accidental sampling technique, and statistical data processing in the form of processing validity and reliability, normality testing, multiple linear regression, simultaneous test (F test), partial test ( $T$ test) and test coefficient of determination with the number of respondents as many as 100 customers. The results of this study indicate that partially Information Quality, Trust and Satisfaction have a significant effect on customer participation. Simultaneously, the variables of Information Quality, Trust and Satisfaction have an effect on Customer Participation in Shopee Online Shop Customers in Rantauprapat.
\end{abstract}

Keywords

information quality; trust; customer satisfaction; customer participation.

\section{Introduction}

Economic growth and technological developments in Indonesia are developing very rapidly, it can be seen by the increasing number of internet users. Internet can provide convenience for its users so that users can access the internet anywhere and anytime. The rapid growth of the internet in Indonesia is also published in a news article which states that based on the results of the Indonesian Polling study in collaboration with the Indonesian Internet Service Providers Association (APJII), it is stated that the penetration survey for internet users in Indonesia from 2019 to quarter II in 2020 has increased. . Based on the survey results, the number of internet users has increased to reach 196.7 million users in 2020, the number of internet users in Indonesia is 73.7 percent (APJII, 2020).

The increasing number of internet users in Indonesia has made the growth of electronic commerce or often called e-commerce (electronic commerce). E-commerce is a term used for shopping activities accessed through an online-based internet network. The internet plays a very important role in supporting the development of e-commerce, especially in increasing buying and selling transactions. Currently, many business actors have switched to using ecommerce with the marketplace model as a medium to market their products. E-commerce applications are used by the public as a new online-based shopping platform so that buyers don't need to come to the store, they just have to "click" on the e-commerce application (Kangean \& Rusdi, 2020). Because e-commerce applications that are most widely used in Indonesia also attract buying and selling sites such as Bukalapak, Blibli, Lazada, Sociolla, Tokopedia, Orami, Bhinneka, Ralali, JD.ID, Shopee and others. 


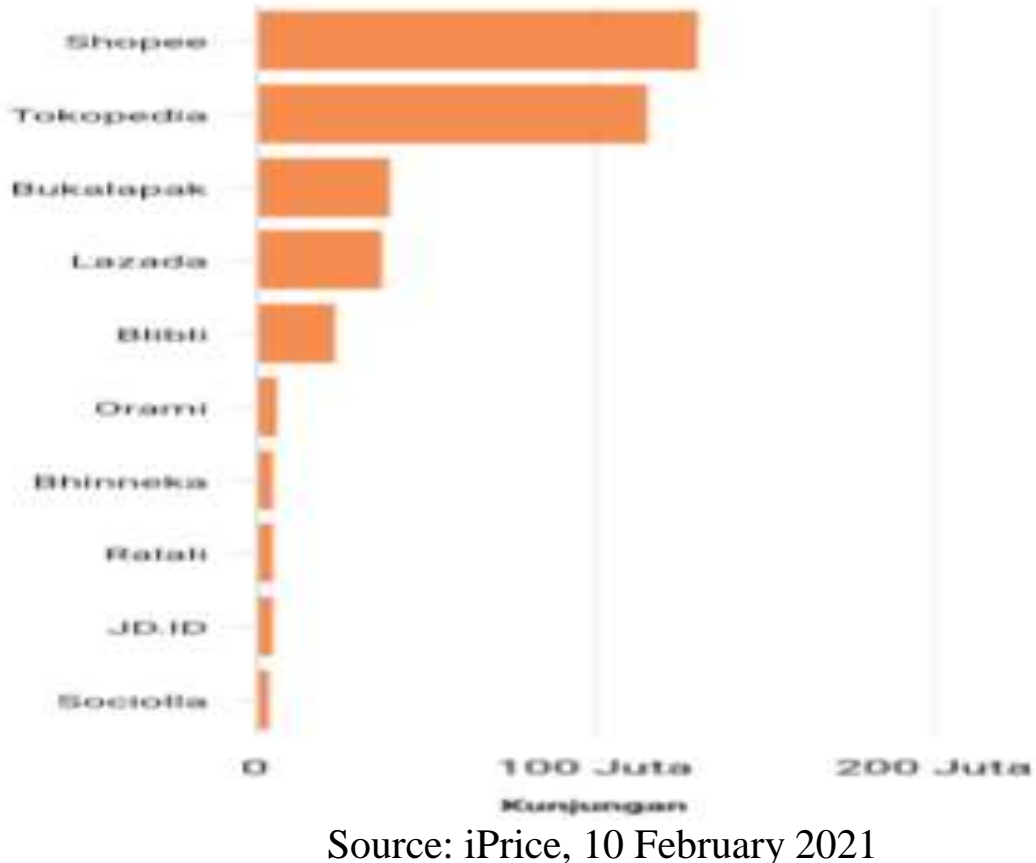

From the graph above shows that the most e-commerce visits in Indonesia are shopees, with a total visitor data of 129.3 million people. Then followed by e-commerce Tokopedia, Bukalapak, Lazada, Blibli, Orami, Bhinneka, Ralali, JD.ID and Sociolla. Shopee is an ecommerce made by Chris Feng that is able to dominate mobile applications by maintaining its first position as the most popular shopping application on the visiting data platform in 2021 (iPrice, 2021) in (Bayu \& Ridhoi, 2021).

Shopee is an electronic trading platform for buying and selling online easily and quickly. Shopee comes in the form of a mobile application and website to make it easier for its users to carry out online shopping activities. Shopee is an e-commerce company originating from Singapore under the auspices of the Garena company. Shopee started to enter Indonesia on December 1, 2015. Shopee became e-commerce with the number of transactions in the first place with the largest number of website visitors in Indonesia. During the fourth quarter (per month of October to December) 2020, the average monthly visit to Shopee was recorded at 129.3 million. This makes shopee ranks first in Indonesian ecommerce after shifting the popularity of Tokopedia with the first order transactions in the first quarter (per January to March) 2019 (Kangean \& Rusdi, 2020). Shopee is an ecommerce application that serves online buying and selling transactions containing various kinds of goods and services. Products sold range from clothing, cosmetics, mobile devices, and all kinds of other goods. In addition, Shopee can also be used to purchase pulses, electricity tokens, meal vouchers, and others.

From the phenomenon that occurs, it can be seen that the Shopee site as an online buying and selling site is able to rank first by beating the popularity of the Tokopedia buying and selling site, and what's interesting about this problem is how the strategies Shopee must do to stay afloat in increasing customer participation in deciding to buy so that it remains the number one buying and selling site in Indonesia and cannot be shifted by other e-commerce.

The ease of shopping online makes everyone flock to shop according to individual and group needs. But some results from interviews and interviews with e-commerce customers are a problem that makes people afraid to shop online. This fear stems from mismatched 
goods information, incorrect delivery of goods on time, to items that don't arrive. This is what makes it problematic to participate in online shopping.

The thing that keeps consumers in mind is their level of trust in sellers on the internet. Without the trust of the customer, a transaction is unlikely to occur. Therefore, building trust from customers is something that must be done by sellers because without trust, it is difficult for a business to run. Customer participation in shopee e-commerce trust is still in doubt due to several obstacles that occur in the field. According to (Satisfaction et al., 2020) argues that after consumers buy these products consumers can be satisfied or dissatisfied and engage in post-purchase behavior. Customer satisfaction will appear when the goods are ordered according to their wishes.

Customer participation in always using e-commerce will grow well if sellers are able to maintain the trust that has been given by consumers. With this, e-commerce companies must maintain existing customers by fostering a sense of satisfaction for every customer who will continue to participate again using Shopee e-commerce. Therefore the authors are interested in making a study entitled "Analysis of Information Quality, Trust, and Satisfaction with Customer Participation (Case Study at Shopee's Online Shop in Rantauprapat).

\section{Review of Literature}

\subsection{Quality of Information}

According to (Gunawan \& Ayuningtiyas, 2018), the information presented in the online shop should include information related to products and services available in online shopping. This information should be useful and relevant in predicting the quality and usefulness of products and services. To be able to satisfy the information needs of online consumers, product and service information must be up-to-date, so that it can help online buyers make decisions, be consistent and easy to understand. Quality of information, namely customer perceptions of the quality of information about products or services provided by the site, the more quality information provided to quality online buyers, the higher the interest of online buyers to buy these products (Ikhsan \& Krisnadi, n.d.). According to (Rachmawati et al., 2019) information is data that has been processed into a form that has meaning for the recipient and has real value and is felt for current decisions or future decisions, how much information about products and services is useful and relevant for online shoppers in predicting.

\subsection{Trust}

According to (Shopping et al., 2021) the key to success in online business is trust because with trust it will be very easy for businesses to keep consumers using the online marketplace. Establishing online brand trust can also trigger consumers to want to make purchases on the online marketplace. Trust is a very important factor to stimulate online purchases. In addition, trust is also a way to deal with uncertainty faced by consumers. Therefore it is important for companies to form brand trust in order to survive in the market. According to (Ashghar \& Nurlatifah, 2020) to get consumer loyalty, you must first earn their trust. Consumer trust has been recognized in the marketing literature as an important factor for successful business trading, as well as development and management for long-term relationships (Japarianto \& Adelia, 2020). Trust is a consumer factor in deciding to purchase a product online (Harun \& Ayu Salmah, 2020). 


\subsection{Satisfaction}

Customer satisfaction means the comparison between what consumers expect and what consumers feel when using the product. When consumers feel the product's performance equals or exceeds their expectations, it means they are satisfied. Conversely, if the product's performance is less than expectations, it means they are not satisfied. Satisfaction According to (Fikri et al., 2020) customer satisfaction is a measure of whether a product is good or bad in meeting customer expectations. Satisfaction becomes an expectation after a purchase and becomes the basis for fulfillment before reaching customer participation. According to (Jufrizen et al., 2020), consumers are satisfied: they will make repeat purchases, increasing the desire to make online purchases. There is a positive relationship between customer satisfaction and repurchase intention. Consumers who are satisfied with online shopping performance have an influence on re-purchase intentions. So that customer satisfaction has an important effect on increasing repurchase intentions. According to (Latifah et al., 2020) explaining that consumer satisfaction is influenced by trust in products so as to shape consumer attitudes and behavior in making repeat purchases in e-commerce. The level of satisfaction for every people is different (Syamsuri \& Siregar, 2018). Siregar et al., (2020) difines satisfaction as positive attitude or feeling positive for everything person received.

\subsection{Customer Participation}

Participation is a person's involvement in a particular activity. In the context of ecommerce, participation is measured by the number of consumers making transactions. Participation in e-commerce will grow well if sellers are able to maintain the trust that consumers have given them. When consumers feel that the seller has properly maintained the trust given, the consumer will be happy to continue to increase their participation. Even in certain situations consumers will invite or notify their colleagues to participate in these activities (Ridwan, 2019). Customer participation is something that affects the quality of production results so that customer satisfaction can be achieved (Gunarso et al., 2020).

Participation does not only involve oneself physically, but also relates to other people, giving rise to a sense of responsibility in community groups. Participation in the economic sector, such as service providers and consumers, has various potential benefits. Consumers have convenient access and service providers can benefit in the economic field. Participation offers sharing opportunities in strengthening a business for the surrounding environment. Meanwhile, customer participation in providing the right direction to build a business in providing the best service. Thus, participation is a person's willingness to get involved so as to produce success in many ways (Participation et al., 2020).

\subsection{Analysis of the Quality of Information on Customer Participation}

According to (Koentjoro et al., 2020) the quality of information greatly influences consumers in deciding a purchase, the better the quality obtained by consumers, the more it will increase as customer participation in purchasing the product. This can be seen in the ease of information that helps consumers to compare the products they will buy so that consumers are confident in making purchasing decisions. (Rendy Putra Pradwita et al., 2020) defines the quality of information as the customer's perception of the quality of information provided by a website. The more quality the information provided to online buyers, the higher the interest of online buyers to buy the product. According to (Pratomo 2015) providing accurate information will be able to reduce complaints that consumers provide. The quality of information is the result of an information system in the form of the quality of the output of an information, the better the quality of the information, the more appropriate purchasing 
decisions made by consumers, as well as information conveyed correctly, consumers can make purchasing decisions more quickly.

Quality of service also plays an important role in attracting undergraduate graduates to register. Arief (2007) states that customers are increasingly skilled in their requests and increasingly demanding higher service standards. If the service quality felt by students during the lecture is satisfactory, then directly or indirectly. (Fortunata and Toni, 2020)

\subsection{Analysis of Trust in Customer Participation}

Customer trust provides a more positive spirit for members of the virtual community in recommending other community members not to worry (feel at risk) in making transactions through e-commerce. Members who have a greater involvement experience in e-commerce will have a lower feeling of the risk of transacting through e-commerce compared to members who are less involved (Operator et al., 2018). Customer trust is an important factor in recommending transactions via e-commerce. Customer trust has been proven to increase customer participation in e-commerce. Trust positively influences the decision to shop online because consumers believe that the company is able to carry out online activities (because of competence) and can deliver the products purchased to consumers. If consumers trust the online store provided by the company, this will allow them to increase their intention to make purchases online (Ridwan, 2019). Customer participation can also be defined as actions and activities that aim to influence customer input into the production and delivery of services to increase positive outcomes and reduce negative consequences for service providers and customers (Mustak et al., 2016).

\subsection{Analysis of Satisfaction with Customer Participation}

Customers feel satisfied from the experience they have felt and lead to customer satisfaction. Customers who are satisfied with the service that has been received will make these customers believe in the company and have high hopes that they will reuse the service in the future. (Gultom et al., 2020) emphasize that there are many benefits received by companies by achieving high customer satisfaction, one of which is customer participation.

According to (Satisfaction et al., 2020) argues that after consumers buy these products consumers can feel satisfied or dissatisfied and can be seen in post-purchase behavior. Satisfied customers buy products again, praise the products they bought in front of others, draw little attention to competitors' brands and advertisements and buy other products from the same company.

\section{Research Methods}

The object of this research is the Shopee online shop customers located in Rantauprapat City, Labuhanbatu Regency, North Sumatra Province. The method used in this study is nonprobability sampling with accidental sampling technique. Because the population was taken by chance using a questionnaire. According to Hair et al (2014), it was suggested that the appropriate sample size ranged from 100-200 respondents. In this study, the number of samples used was 100 respondents who felt that they were sufficient to represent the population. Respondent collection cannot be done directly because of limited time and distance. The data was collected online by distributing the questionnaire link using the google

form. Test instruments and to test research hypotheses using the SPSS Statistic 20 technique as follows: 
Table 1.Test Results of Validity and Variable Reliability

\begin{tabular}{|c|c|c|c|c|c|}
\hline No & Variables and Indicators & $\begin{array}{c}\text { Corrected } \\
\text { Item-Total } \\
\text { Correlation }\end{array}$ & Information & $\begin{array}{c}\text { Cronbach } \\
\text { Alpha }\end{array}$ & Information \\
\hline $\mathbf{A}$ & $\begin{array}{l}\text { Quality of Information } \\
\text { (X1) }\end{array}$ & & Valid & & \\
\hline 1 & KI1 & 0,688 & Valid & \multirow{4}{*}{0,760} & \multirow{4}{*}{ Reliabel } \\
\hline 2 & KI2 & 0,684 & Valid & & \\
\hline 3 & KI3 & 0,390 & Valid & & \\
\hline 4 & KI4 & 0,490 & Valid & & \\
\hline $\mathbf{B}$ & Trust (X2) & & Valid & & \\
\hline 1 & Trust1 & 0,683 & Valid & \multirow{4}{*}{0,855} & \multirow{4}{*}{ Reliabel } \\
\hline 2 & Trust2 & 0,452 & Valid & & \\
\hline 3 & Trust3 & 0,739 & Valid & & \\
\hline 4 & Trust4 & 0,673 & Valid & & \\
\hline 5 & Trust5 & 0,818 & Valid & & \\
\hline $\mathbf{C}$ & Satisfaction (X3) & & Valid & & \multirow{5}{*}{ Reliabel } \\
\hline 1 & Satisfaction1 & 0,599 & Valid & \multirow{4}{*}{0,768} & \\
\hline 2 & Satisfaction2 & 0,419 & Valid & & \\
\hline 3 & Satisfaction3 & 0,680 & Valid & & \\
\hline 4 & Satisfaction4 & 0,657 & Valid & & \\
\hline $\mathbf{D}$ & $\begin{array}{l}\text { Customer Partisipation } \\
(\mathbf{Y})\end{array}$ & & Valid & & \\
\hline 1 & Parpel1 & 0,621 & Valid & \multirow{5}{*}{0,814} & \multirow{5}{*}{ Reliabel } \\
\hline 2 & Parpel2 & 0,617 & Valid & & \\
\hline 3 & Parpel3 & 0,662 & Valid & & \\
\hline 4 & Parpel4 & 0,620 & Valid & & \\
\hline 5 & Parpel5 & 0,578 & Valid & & \\
\hline
\end{tabular}

Source: Results of SPSS data processing, 2021 (Processed by Research)

Based on the table above, the test results of the validity and reliability test, a measurement scale is said to be valid or invalid for an indicator if the Corrected Item-Total Correlation value is greater than 0.361 . To determine the reliability of each research variable, a Cronbach Alpha value $>0.70$ was used. So from all variables that 18 indicator items are declared invalid because the Corrected Item-Total Correlation value is smaller than 0.361 while the others are valid, this can be seen from the Corrected Item-Total Correlation value greater than the specified 0.361 . Then a construct or variable is said to be reliable if the Cronbach Alpha> 0.70. From the results in the table above, the reliability test shows that the Cronbach Alpha value is greater than 0.70, so the question instrument is declared good or reliable. 


\section{Results and Discussion}

\subsection{Classic Assumption Test}

Table 2. One-Sample Kolmogorov-Smirnov Test

\begin{tabular}{|ll|r|}
\hline & & $\begin{array}{c}\text { Unstandardized } \\
\text { Residual }\end{array}$ \\
\hline $\mathrm{N}$ & Mean & 100 \\
Normal Parameters ${ }^{\mathrm{a}, \mathrm{b}}$ & Std Deviation & 1.72329877 \\
& Absolute & .173 \\
Most Extreme Differences & .159 \\
& Positive & -.173 \\
Kolmogorov-Smirnov Z & Negative & 1.732 \\
Asymp Sig. (2-tailed) & & .005 \\
\hline
\end{tabular}

a. Test distribution is Normal.

b. Calculated from data.

Source: Results of SPSS data processing, 2021 (Processed by Research)

In table 2 . The normality test above, the results of the normality test of the residual data are normally distributed

Table 3.Uji Multikolinieritas Coefficientsa

\begin{tabular}{|ll|r|r|l|}
\hline \multirow{2}{*}{ Model } & \multicolumn{2}{|c|}{ Colinearity Statistics } & \multirow{2}{*}{ Information } \\
\cline { 3 - 4 } & Tolerance & \multicolumn{1}{|c|}{ VIF } & \\
\hline 1 & KI & .631 & 1.584 & Multicollinearity does \\
& TRUST & .486 & 2.057 & not occur \\
& SATISFACTION & .488 & 2.050 & Multicollinearity does \\
& & & not occur \\
& & & Multicollinearity does \\
& & & not occur \\
& & & \\
\hline
\end{tabular}

a. Dependent Variable : PARPEL

In table 3.The Multicollinearity Test is actually the fact that is processed to create a Multicollinearity Test with the tolerance number for all variables above 0.1 and the VIF number is below 10, it can be concluded that if there is no relationship between the independent variables used or there are no problems in the Multicollinearity Test. 


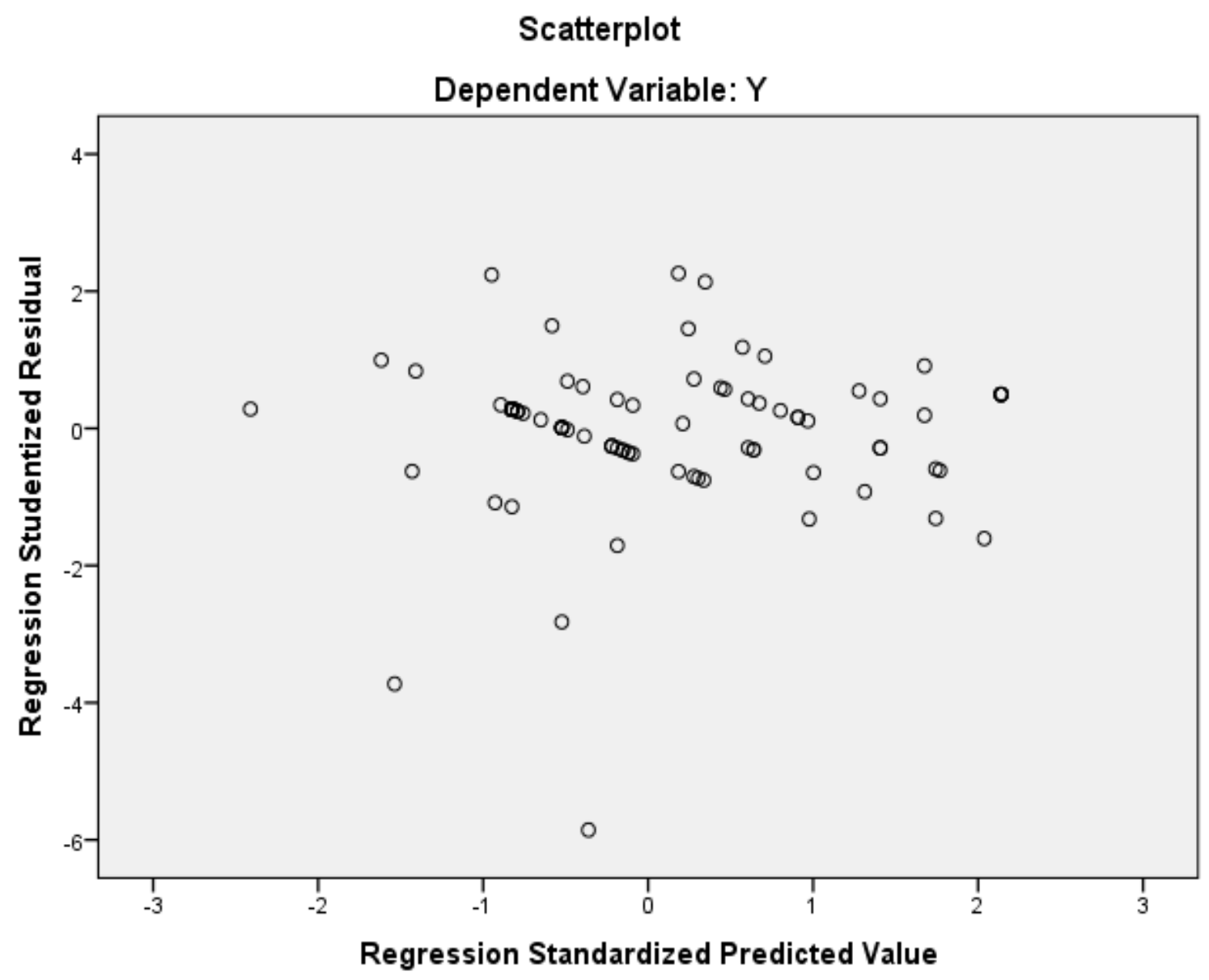

Figure 1. Scatterplot Graph of Heteroscedasticity Test

From the output above, it can be seen that the distribution of the residuals is irregular and the plot does not form a certain pattern. So it can be concluded that there are no symptoms of heteroscedasticity in the regression model.

Table 4. Uji Autokorelasi Runs Test

\begin{tabular}{|l|r|}
\hline & \multicolumn{2}{|c|}{$\begin{array}{c}\text { Unstandardized } \\
\text { Residual }\end{array}$} \\
\hline Test Value & .38554 \\
Cases $<$ Test Value & 49 \\
Cases >= Test Value & 51 \\
Total Cases & 100 \\
Number of Runs & 58 \\
Z & 1.412 \\
Asymp. Sig. (2-tailed) & .158 \\
\hline
\end{tabular}

a.Median.

In table 4. Autocorrelation test that the processed information creates the Asymp value. Sig. (2-tailed) obtained between above 0.05 (0.158), it can be concluded that the form of regression does not have problems in the autocorrelation test. 


\subsection{Simultaneous Test Results (Test F)}

Table 5. Statistical Test Results F ANOVAa

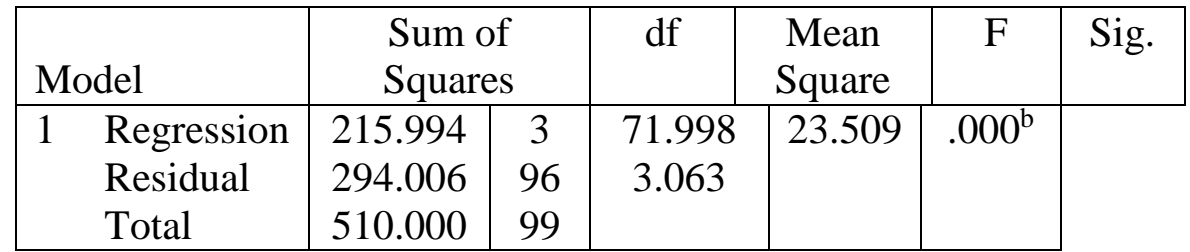

a. Dependent variable : PARPEL

b. Predictors : (constant), SATISFACTION, KI, TRUST

From table 5 above, the probability value of $\mathrm{F}$ sig is 0,000 ( $\operatorname{Sig} 0,000<\propto 0.05$. Means that $\mathrm{HO}$ is rejected and accepts $\mathrm{H} 1$, so the result of the independent variables consists of: information quality variable (X1), trust variable (X2), satisfaction variable ( X3) Towards the dependent variable: customer participation variable (Y) Case Study on Shopee Online Shop Customers in Rantauprapat.

\subsection{Partial Test Result (t test)}

Table 6. Results of the Equation Statistical Test Coefficientsa

\begin{tabular}{|c|c|c|c|c|c|c|}
\hline \multirow{2}{*}{\multicolumn{2}{|c|}{ Model }} & \multicolumn{2}{|c|}{$\begin{array}{c}\text { Unstandardized } \\
\text { Coefficients }\end{array}$} & \multirow{2}{*}{$\begin{array}{c}\text { Standardized } \\
\text { Coefficients }\end{array}$} & \multirow[b]{2}{*}{$\mathrm{T}$} & \multirow[b]{2}{*}{ Sig. } \\
\hline & & B & Std. Error & & & \\
\hline & (Constant) & 1.701 & 1.816 & & .936 & .351 \\
\hline & $\mathrm{KI}$ & 0.450 & .157 & .280 & 2.869 & .005 \\
\hline & TRUST & -.015 & .127 & -.013 & -.119 & .905 \\
\hline & SATISFACTION & .645 & .155 & .462 & 4.168 & .000 \\
\hline
\end{tabular}

a. Dependent variable: PARPEL

The statistical test results of the equation ( $\mathrm{T}$ test) create a regression equation, namely: $\mathrm{Y}=1.701-0.450 \mathrm{X} 1+(-0.015) \mathrm{X} 2+0.645+\mathrm{e} \_2$ so that the Sig. Information Quality variable $0.005<0.05$ and significant effect on the dependent variable $\mathrm{Y}$ customer participation. Sig value. The trust variable $0.905<0.05$ has a significant and significant effect on the dependent variable Y customer participation. As well as the Sig. The satisfaction variable $0.000<0.05$ has a significant effect on the dependent variable Y Customer participation in Shopee's online shop customers.

\subsection{Coefficient of Determination}

Table 7. Coefficient of Determination Model Summary ${ }^{\mathrm{b}}$

\begin{tabular}{|c|c|r|r|r|}
\hline Model & $\mathrm{R}$ & R Square & $\begin{array}{c}\text { Adjusted R } \\
\text { Square }\end{array}$ & $\begin{array}{c}\text { Std. Error of } \\
\text { the Estimate }\end{array}$ \\
\hline 1 & $.651^{\mathrm{a}}$ & .424 & .406 & 1.75002 \\
\hline
\end{tabular}

a. Predictors: (Constant). SATISFACTION, KI, TRUST

b. Dependent Variable: PARPEL

Based on the results of the SPSS software output above, the R Square value is 0.424. This shows that there is a strong relationship between information quality variables, trustworthiness, satisfaction by simultaneously influencing customer participation by $42.4 \%$ and the remaining $57.6 \%$ influenced by other factors. 


\subsection{Analysis of Information Quality on Customer Participation}

The results of research that have been processed by researchers through SPSS 20, the results of this study indicate that partially it can be understood that the variable quality of information has a positive and significant impact on customer participation. As shown in table 6. The results of the statistical equation test if the number is Sig. variable information quality $0.005<0.05$ affects and is significant on the dependent variable Y. Information quality, trust, and satisfaction have a positive influence on customer participation in a case study on Shopee Online Shop customers in Rantauprapat accepted. Accuracy in information quality is characterized by the accuracy of information provided to consumers without giving errors and being able to explain what is meant (Romla \& Ratnawati, 2018). The results of this study support previous researchers that have been carried out by Rohmah (2019) that the responses of respondents in the questionnaire research that have been distributed to online shop shopee customers prefer shopping on the site because shopees provide information that consumers can accept with their expectations

\subsection{Analysis of Trust in Customer Participation}

Based on the results of research that have been processed by researchers through SPSS 20 , the results of the study in a partial way can be understood that the variable of trust has a positive and significant effect on customer participation. As shown in table 6. The results of the statistical equation test if the number is Sig. information quality variable $0.905<0.05$ affects and is significant in the dependent variable Y. Information quality, trust, and satisfaction have a positive influence on customer participation in a case study on Shopee Online Shop customers in Rantauprapat accepted. Shopee consumers feel confident when shopping because shopee provides information about every product that makes consumers feel that it gives the impression of shopee's honesty in the online buying and selling system. Trust can arise when consumers get certainty from the parties concerned or others, in this case a testimonial of a product that has been purchased by other people (Istiqomah et al., 2019). The results of this study support previous researchers conducted by Dwi (2019) who stated that the higher the level of consumer confidence, the higher the level of customer participation.

\subsection{Customer Satisfaction Analysis of Participation}

Based on the research results that have been processed by researchers through SPSS 20, the results of the research in a partial way can be understood that the satisfaction variable has a positive and significant effect on customer participation. As shown in table 6 . The results of the statistical equation test if the number is Sig. information quality variable $0.000<0.05$ affects and is significant on the dependent variable Y. Information quality, trust, and satisfaction have a positive influence on customer participation in a case study on Shopee Online Shop customers in Rantauprapat accepted. Satisfied Shopee users tend to intend to make repuchase intention on Shopee e-commerce. It can be interpreted that customer satisfaction with indicators of customer enjoyment (consumer pleasure). Customer benefit (consumer benefit) convenience (convenience) is a factor that encourages consumers to intend to participate in customer participation in e-commerce shopee. Based on the index value the highest answer is in the convenience indicator variable where customers agree that the payment method simplifies the transaction process so that it creates convenience in online shopping so that consumers become one of the factors that customers feel satisfied so that they are interested in becoming customer participation in e-commerce shopee (Intention \& Shopee 2021). 


\section{Conclusion}

The conclusion obtained from this study is that the variable information quality 0.005 $<0.05$ has a significant and significant effect on the dependent variable $\mathrm{Y}$ using customer participation, the hypothesis is accepted. Trust has a positive and significant effect on customer participation. The hypothesis of the satisfaction variable has a positive effect on customer participation in online shop shopee customers in Rantauprapat. The result of the $\mathrm{R}$ Square test is 0.424 , which means that the independent variables, namely the quality of information, trust and satisfaction, affect its use simultaneously, customer participation is $42.4 \%$ and the remaining is $57.6 \%$.

\section{Recommendation}

For further research, we recommend adding an online consumer review variable, which is very important for Shopee's online shopping consumers. The seller must pay attention to several things, one of which is product suitability. If the information that consumers need is in accordance with the content written by the seller, other consumers in the review complain that the product information obtained is not suitable, but the seller has not corrected the error, then the latest review also has the same statement. So that consumers will hesitate when buying these products. Given the importance of online consumers, Journal of Commerce Education (JPTN) Volume 06 Number 03 of 2018 ISSN: 2337-6708 84 comments, Shopee online shopping also needs to increase the company's disgust by increasing the credibility of today's sellers. , Consumers will always be able to make purchasing decisions at Shopee.I

\section{References}

APJII. (2020). Buletin APJII. In Asosiasi Penyelenggara Jasa Internet Indonesia (p. 1). https://apjii.or.id/content/read/104/503/BULETIN-APJII-EDISI-74---November-2020

Ashghar, S. A., \& Nurlatifah, H. (2020). Analisis Pengaruh Perceived Ease of Use, Perceived Usefulness, dan Perceived Risk terhadap Keinginan Membeli Kembali melalui e-Trust dan s-Satisfaction (Studi Kasus Pengguna Gopay pada Transaksi UMKM). Jurnal Al Azhar Indonesia Seri Ilmu Sosial, 1(1), 40. https://doi.org/10.36722/jaiss.v1i1.459

Bayu, D. J., \& Ridhoi, M. A. (2021). 10 E-commerce dengan Pengunjung Terbesar pada Kuartal IV 2020. Databoks.Katadata.Co.Id, datapublish. https://databoks.katadata.co.id/datapublish/2021/02/11/10-e-commerce-denganpengunjung-terbesar-pada-kuartal-iv-2020\#

Berbelanja, P., Kepercayaan, T., Online, M., Ardiyanto, F., \& Imam, A. (2021). Aktiva Jurnal Manajemen dan Bisnis Pengaruh Keamanan, Kualitas Informasi, Word of Mouth Electronic dan. 1(1), 16-25.

Dwi, M. N. (2018). Pengaruh Kepercayaan, Kualitas Informasi, dan Persepsi Resiko Terhadap Keputusan Pembelian (Studi Kasus Pada Pelanggan Online Shop Shopee di Kota Yogyakarta). 1-126.

Fikri, M. El, Ahmad, R., \& Harahap, R. (2020). Strategi Mengembangkan Kepuasan Pelanggan Online Shop Dalam Meningkatkan Penjualan (Studi Kasus Sabun Pyari). $\begin{array}{llll}\text { Jurnal Manajemen } & \text { Tools, } & \text { 87-105. }\end{array}$ https://doi.org/10.1017/CBO9781107415324.004

Fortunata, R and Toni, N. (2020). The Influence of Service Quality, Tuition Fee and Promotion on Student Decisions to Continue Study in Postgraduate of Prima Indonesia University. Budapest International Research and Critics Institute-Journal (BIRCIJournal). P. 829-837. 
Gultom, D. K., Arif, M., \& Fahmi, M. (2020). Determinasi Kepuasan Pelanggan Terhadap Loyalitas Pelanggan Melalui Kepercayaan. Maneggio: Jurnal Ilmiah Magister Manajemen, 3(2), 171-180.

Gunarso, L., Andriano, J., \& Sihombing, S. O. (2020). Keterhubungan Antara Kemampuan, Kebajikan (Benevolence), Dan Integritas Perusahaan Terhadap Kepercayaan Dan Partisipasi Pelanggan: Studi Empiris Pada Tokopedia. Jurnal Muara Ilmu Ekonomi Dan Bisnis, 4(2), 330. https://doi.org/10.24912/jmieb.v4i2.8402

Gunawan, H., \& Ayuningtiyas, K. (2018). Pengaruh Kepercayaan, Kemudahan Dan Kualitas Informasi Terhadap Keputusan Pembelian Daring Di Aplikasi Bukalapak Pada Mahasiswa Politeknik Negeri Batam. Journal of Applied Business Administration, 2(1), 152-165. https://doi.org/10.30871/jaba.v2i1.763

Harun, A., \& Ayu Salmah, N. N. (2020). Pengaruh Kepercayaan dan Kemudahan Terhadap Keputusan Pembelian Online Melalui Aplikasi Shopee. Jurnal Media Wahana Ekonomika, 17(2), 114. https://doi.org/10.31851/jmwe.v17i2.4318

Ikhsan, M., \& Krisnadi, I. (n.d.). ... Dan Kualitas Informasi Terhadap Keputusan Pembelian Secara Online (Studi Empiris Pada Konsumen Shopee Di Kota Tangerang). Academia.Edu.

https://www.academia.edu/download/64999765/Pengaruh_Kepercayaan_dan_Kualitas_ Iformasi_terhadap_Keputusan_Pembelian_secara_online.pdf

Intention, R., \& Shopee, P. E. (2021). KORELASI. 2, 677-689.

Istiqomah, Hidayat, Z., \& Jariah, A. (2019). Analisis Pengaruh Kepercayaan , Iklan dan Persepsi Resiko terhadap Keputusan Pembelian di situs Shopee di Kota Lumajang. Jurnal Progress Conference, 2(July), 557-563.

Japarianto, E., \& Adelia, S. (2020). Pengaruh Tampilan Web Dan Harga Terhadap Minat Beli Dengan Kepercayaan Sebagai Intervening Variable Pada E-Commerce Shopee. Jurnal Manajemen Pemasaran, 14(1), 35-43. https://doi.org/10.9744/pemasaran.14.1.35-43

Jufrizen, J., Daulay, R., Sari, M., \& Nasution, M. I. (2020). Model Empiris Peningkatan Kepuasan Dan Niat Beli Konsumen Dalam Pemilihan Online Shop Instagram. Mix Jurnal Ilmiah Manajemen, 10(2), 249. https://doi.org/10.22441/mix.2020.v10i2.008

Kangean, S., \& Rusdi, F. (2020). Analisis Strategi Komunikasi Pemasaran dalam Persaingan E-Commrece di Indonesia. Prologia, 4(2), 280. https://doi.org/10.24912/pr.v4i2.6504

Kepuasan, P., Terhadap, P., Beli, M., Official, P., Scarlett, S., Shopee, D. I., \& Tokopedia, D. A. N. (2020). The Effect Of Customer Satisfaction On Repurchase Interests At The Scarlett Official Store At Shopee And Tokopedia. 7(2), 6476-6489.

Koentjoro, W., Fajrian, A., \& Belakang, L. (2020). Model Peningkatan Penjualan Online Berdasarkan Persepsi. 995-1007.

Latifah, N., Widayani, A., \& Normawati, R. A. (2020). Pengaruh Perceived Usefulness Dan Trust Terhadap Kepuasan Konsumen Pada E- Commerce Shopee. BISMA: Jurnal Bisnis Dan Manajemen, 14(1), 82. https://doi.org/10.19184/bisma.v14i1.13550

Mustak, M., Aino, E. \& Kaartemo, H. (2016). Customer participation management Developing a comprehensive framework and a research agenda. Journal of Service Management, 27(3), 250 - 275. http://dx.doi.org/10.1108/JOSM-01-2015-0014

Operator, K., Dasar, S., Di, N., \& Prabu, A. A. A. (2018). Jurnal SWOT , Volume VIII , No 1 , Januari 2018 Jurnal SWOT, Volume VIII , No 1, Januari 2018. VIII(1), 171-187.

Participation, P., Wulan, P., \& Car, R. (2020). No Title. 6(3), 259-273.

Pratomo, D. S dan Astuti, E. Z. (2015). Analisis Regresi dan Korelasi Antara Pengunjung dan Pembeli terhadap nominal pembelian di Indomaret Kedungmundu Semarang dengan Metode Kuadrat Terkecil. Semarang: Universitas Dian Nuswantoro 
Rachmawati, I. K., Handoko, Y., Nuryanti, F., Wulan, M., \& Hidayatullah, S. (2019). Pengaruh kemudahan, kepercayaan pelanggan dan kualitas informasi terhadap keputusan pembelian online. Seminar Nasional Sistem Informasi 2019, 3(September), 1617-1625.

Rendy Putra Pradwita, R. B., Handoko, Y., \& Rachmawati, I. K. (2020). Pengaruh Kepercayaan, Kemudahan, Dan Kualitas Informasi Pada Website Www.Laroslaptop.Com Terhadap Keputusan Pembelian Online. Jurnal Apresiasi Ekonomi, 8(2), 212-220. https://doi.org/10.31846/jae.v8i2.312

Ridwan, M. (2019). Terhadap Kepercayaan Pelanggan Dan Dampaknya Pada Partisipasi Pelanggan E-Ecommerce Di Indonesia. 24(2), 79-93.

Rohmah, H. (2019). Analisis Pengaruh Kepercayaan, Kemudahan, Kualitas Informasi, Produk Halal Terhadap Keputusan Pembelian Online Pada Mahasiswa Prodi Ekonomi Islam Agkatan 2016-2018 UIN Walisongo di Marketplace Shopee.

Romla, S., \& Ratnawati, A. (2018). Keputusan Pembelian E-Commerce Melalui Kemudahan Penggunaan, Kualitas Informasi Dan Kualitas Interaksi Layanan Web. Jurnal Ekonomi Dan Bisnis, 19(1), 59. https://doi.org/10.30659/ekobis.19.1.59-70

Siregar, Z. M. E., Syahputra, R., \& Nasution, S. L. (2020). Pengaruh Keadilan Organisasional terhadap Komitmen Organisasi : Peran Mediasi Kepuasan Kerja. JSHP ( Jurnal Sosial Humaniora Dan Pendidikan), 4(2), 82-92.

Syamsuri, A. R., \& Siregar, Z. M. E. (2018). Analisis Pelatihan, Disiplin Kerja, Remunerasi, dan Motivasi Berprestasi dengan Kepuasan Kerja Sebagai Variabel Intervening terhadap Kinerja Karyawan. JSHP ( Jurnal Sosial Humaniora Dan Pendidikan), 2(2), 95. https://doi.org/10.32487/jshp.v2i2.470 